\title{
Pemilihan Umum Indonesia antara Demokrasi Pancasila dan Demokrasi Liberal
}

\author{
Anak Agung Ngurah Agung Wira Bima Wikrama \\ Fakultas IImu Sosial dan IImu Politik \\ Universitas Mahendradatta \\ Email: bimawikrama65@gmail.com
}

\begin{abstract}
General election is a tools or facility in implementing democracy which is carried out directly, publicly, freely, confidentially, honestly and fairly. This is in accordance with the principle of democracy, namely from the people, by the people, and for the people as mandated by Article 1 paragraph 2 of the 1945 Constitution. The election is believed to be only as one instrument to encourage the democratic process. Because the increase of mature democracy will reduce injustice and make people's lives more secure in their freedom and encourage the creation more a fair. However, democracy which is carried out through general election in Indonesia now adays is not democracy and the general which is election very suitable for Indonesia. Indonesia has a democratic style mechanism and only exists in Indonesia. Indonesian democracy has been very clearly stated in the $4^{\text {th }}$ principle of Pancasila, which is popularly led by wisdom in deliberation/representation. For this reason, awareness is needed by state leaders and elected board members to be able to understand and explore the values and spirits of Indonesians style democracy. So that Indonesians democracy is getting closer to the spirit and body of Indonesias people.
\end{abstract}

Keywords: general election, democracy, Pancasila.

\section{LATAR BELAKANG}

Pemilihan umum merupakan alat atau sarana dalam pelaksanaan demokrasi yang dilaksanakan secara langsung, umum, bebas, rahasia, jujur dan adil. Hal ini sesuai dengan prinsip-prinsip demokrasi yaitu dari rakyat, oleh rakyat, dan untuk rakyat seperti yang diamanatkan oleh Undang Undang Dasar 1945 pasal 1 ayat 2. Pemilihan umum diyakini hanya sebagai salah satu instrument untuk mendorong proses demokrasi. Karena demokrasi yang semakin matang akan mengurangi ketidak adilan dan membuat kehidupan masyarakat semakin terjamin kebebasannya dan mendorong terciptanya tatanan yang lebih adil. Pemilihan umum diselenggarakan dengan tujuan untuk memilih wakil rakyat baik ditingkat pusat maupun di tingkat daerah serta untuk membentuk pemerintahan yang demokratis. Pemilihan umum diselenggarakan dengan tujuan untuk memilih wakil rakyat baik ditingkat pusat maupun di tingkat daerah serta untuk membentuk pemerintahan yang demokratis, kuat, dan memperoleh dukungan rakyat dalam rangka mewujudkan cita-cita kemerdekaan sebagaimana tercantum dalam mukadimah Undang Undang Dasaar Republik Indonesia 1945.

\section{PEMILIHAN UMUM}

Fungsi dari sistem pemilihan umum adalah untuk mengatur prosedur seseorang untuk dipilih menjadi anggota badan perwakilan rakyat atau sebagai kepala pemerintahan. Sistem pemilihan umum pun diatur dalam undang-undang dan mempunyai tiga variabel pokok, yaitu (a) Penyuaraan (balloting): tata cara yang harus diikuti pemilih yang berhak dalam memberikan suara, (b) Daerah pemilihan (electoral 
district): ketentuan yang mengatur berapa jumlah kursi wakil rakyat untuk setiap daerah pemilihan, (c) Formula pemilihan: rumus yang digunakan untuk menentukan siapa atau partai politik apa yang memenangkan kursi di suatu daerah pemilihan.

Selain itu terdapat pula tiga hal yang menjadi tujuan dari pemilihan umum yaitu (a) pemilihan umum sebagai mekanisme untuk menyeleksi para pemimpin pemerintahan dan alternatif kebijakan umum, (b) pemilihan umum memberi mekanisme pemindahan konflik kepentingan dari masyarakat kepada badan-badan perwakilan rakyat melalui wakil-wakil rakyat yang terpilih atau melalui partai-partai yang memenangkan pemilihan umum sehingga ketertiban masyarakat tetap terjamin, (c) pemilihan umum dapat dijadikan sebagai sarana memobilisasi dan/atau menggalang dukungan rakyat terhadap negara dan pemerintahan dengan jalan ikut serta dalam proses politik.

\section{DEMOKRASI PANCASILA}

Demokrasi Pancasila lahir dari gagasan seorang tokoh bangsa dan sekaligus sebagai pendiri Negara Indonesia yaitu Ir. Soekarno. Demokrasi Pancasila merupakan sebuah perjuangan Bangsa Indonesia untuk mewujudkan cita-cita Indonesia Merdeka, bersatu, berdaulat adil dan makmur. Selain itu, demokrasi Pancasila merupakan produk nasional yang lahir dan digali dari nilai-nilai budaya Bangsa Indonesia yang telah tumbuh subur di Nusantara. Nilai-nilai luhur Bangsa Indonesia inilah yang mengilhami pendiri Bangsa Indonesia untuk meneguhkan kembali keyakinannya tentang sesuatu yang telah berkembang di nusantara sejak jaman kerajaan. Keyakinan tersebut telah tumbuh dan berkembang semjadi ideolagi dan telah disepakati oleh pemimpin bangsa Indosena dan seluruh rakyat Indonesia hingga saat ini.

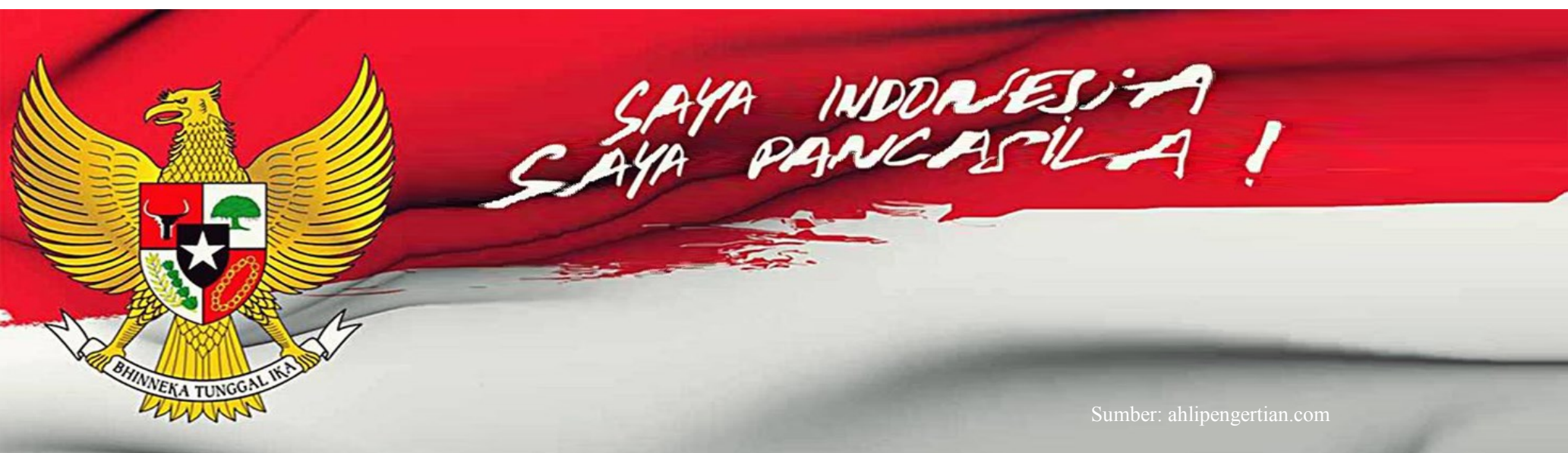

Pengaruh informasi dan globalisasi telah menghadapkan Bangsa Indonesia pada realitas perkembangan jaman yang terus berubah. Seakan-akan perubahan tersebut telah menjadi sebuah keharusan bagi Bangsa Indonesia. Padahal perubahan mendasar yang menyentuh indeologi bangsa dapat mencabut akar demokrasi ala Indonesia. Bangsa Indonesia seakan terlena dan semakin lupa dengan miliknya yang berharga dan menganggap segala yang datangnya dari luar adalah benar dan cocok dengan kepribadiannya. Sungguh sebuah fenomena yang sangat mengkawatirkan bagi kegaulatan demokrasi ala Indonesia. Penyadaran akan keunggulan demokrasi milik Bangsa Indonesia harus senantiasa selalu diungkap ke permukaan supaya 
Bangsa Indonesia menyadari bahwa mereka memiliki nilai demokrasi yang unggul dan sangat cocok dengan keadaban bangsanya sendiri.

Untuk lebih memahami seperti apa Demokrasi ala Indonesia yang kemudian menjadi Demokrasi pancasila, maka penulis ingin mengungkap sebuah fakta tentang ideologi yang berkembang di dunia. Ideologi yang dimaksud adalah adanya dua ideologi yang berkembang yaitu Ideologi terbuka dan Ideologi Tertutup. Yang dimaksud dengan Ideologi Terbuka adalah ideologi yang memiliki sifat inklusif, tidak totaliter, dan tidak dapat dipakai untuk melegitimasi kekuasaan pada sekelompok orang. Dengan demikian ideologi terbuka hanya dapat dilaksanakan pada pemerintahan yang dijalankan dengan sistem yang demokratis. Ideologi terbuka memiliki ciri-ciri seperti: (a) merupakan kekayaan rohani, moral, dan kebudayaan yang berkembang di tengah masyarakatnya, (b) tidak diciptakan oleh pemerintah, tetapi ditemukan atau digali dari budaya masyarakat sendiri, (c) isi ideologi tersebut tidak langsung dapat operasional, sehingga setiap generasi harus terus diajarkan, digali kembali dan mencari implikasinya dalam situasi kekinian mereka, (d) ideologi ini tidak pernah memaksakan kebebasan dan tanggung jawab kepada masyarakat, melainkan menginspirasi masyarakat untuk berusaha hidup bertanggung jawab, (e) menghargai kemajemukan bangsa, sehingga dapat diterima oleh masyarakat yang berasal dari berbagai latar belakang budaya dan agama.

Ideologi tertutup memiliki sifat yang dogmatis dan apriori. Dogmatis dapat diartikan bahwa ideologi ini mempercayai suatu keadaan tanpa data yang valid. Apriori adalah selalu berprasangka terlebih dahulu terhadap suatu keadaan. Ideologi tertutup selalu dipaksakan pemberlakuannya dan harus dipatuhi oleh masyarakat yang diatur oleh golongan elit tertentu atau kelompok masyarakat tertentu. Ideologi tertutup ini bersifat otoriter dan dijalankan dengan cara yang totaliter.

Bagaimana dengan Pancasila? Apakah Pancasila termasuk ideologi terbuka atau tertutup? Pertanyaan tersebut dengan mudah dapat dijawab bahwa Ideologi Pancasila merupakan sebuah ideologist terbuka. Sangat nyata dapat dilihat dan dirasakan oleh seluruh rakyat Indonesia bahwa Ideologi Pancasila yang dianut oleh Bangsa Indonesia bersifat aktual, dinamis, antisipatif, dan senantiasa mampu menyelesaikan suatu permasalahan dengan sesuai perkembangan jaman, ilmu pengetahuan dan teknologi serta dinamika perkembangan aspirasi masyarakat Indonesia. Keterbukaan ideologi Pancasila bukan berati Bangsa Indonesia akan dapat dengan mudah mengubah nilai-nilai dasar yang terkandung di dalam Pancasila tersebut. Namun Bangsa Indonesia dapat mengeksplisitkan wawasannya lebih konkret, sehingga memiliki kemampuan yang reformatif untuk memecahkan masalahmasalah aktual yang senantiasa berkembang seiring dengan aspirasi masyarakat, perkembangan ilmu pengetahuan dan teknologi serta jaman.

Dari segi sosiologis, Karl Mannhein mengatakan bahwa Ideologi dibedakan dalam 2 kategori yaitu ideologi yang bersifat partikular dan ideologi yang bersifat komprehensif. Beliau mengatakan bahwa Ideologi Partikular adalah suatu keyakinan yang tersusun secara sistematis dan terkait erat dengan kepentingan satu kelas sosial tertentu dalam masyarakat. Sedangkan Ideologi Komprehensif adalah suatu sistem pemikiran menyeluruh mengenai semua aspek kehidupan sosial. Dalam ideologi Ideologi Komprehensif ini terdapat suatu cita-cita yang bertujuan untuk melakukan transformasi sosial secara besar-besaran menuju bentuk tertentu yang diinginkan. 
Ideologi Pancasila berada di mana? Ideologi Pancasila berada tengah-tengah kedua ideologi di atas. Hal ini dapat dijelaskan bahwa Ideologi Pancasila memiliki ciri menyeluruh yaitu tidak berpihak pada golongan tertentu dan Ideologi Pancasila dikembangkan dari nilai-nilai yang ada pada realitas Bangsa Indonesia serta mampu mengakomodasikan berbagai idealisme yang berkembang dalam masyarakat yang majemuk.

\section{DEMOKRASI LIBERAL}

Selain ideologi Pancasila seperti yang disebutkan di atas, berkembang pula ideologi lain di dunia yaitu ideologi Liberalisme, Komunisme dan Sosialisme. Ideologi Komunisme dan Ideologi sosialisme tidak dibicarakan pada kesempatan ini karena penulis menganggap kedua ideologi tersebut kecil kemungkinan untuk dapat diterima oleh rakyat Indonesia. Penulis hanya menyandingkan Ideologi Pancasila dengan Ideologi Liberal karena ideologi liberal ini dapat mengancam nilai-nilai dari demokrasi Pancasila yang diyakini oleh Bangsa Indonesia.

Liberalisme adalah sebuah nilai yang berkembang di negara barat khususnya Negara Amerika. Ideologi ini sangat pesat perkembangannya karena membonceng perkembangan jaman yang disebut modernitas dan pasar bebas. Paham liberalisme memberikan penekanan pada kebebasan individu sehingga kesejahteraan bukan menjadi tanggung jawab negara. Pada ideologi liberal ini berkembang prinsip-prinsip yang mendasar yaitu (a) pengakuan terhadap hak-hak asasi warganegara (b) memungkinkan tegaknya tertib masyarakat dan negara atas supremasi hukum (c) memungkinkan lahirnya pemerintah yang demokratis (d) penolakan terhadap pemerintahan otoriter .

\section{IDEOLOGI DAN DEMOKRASI}

Bagaimana kaitan antara ideologi dan demokrasi? sebuah pertanyaan umum yang sering diutarakan oleh masyarakat. Ideologi merupaka gagasan besar dari pendiri bangsa atau pemimpin bangsa tersebut yang diyakini dan dipelajari secara terus menerus dari generasi ke generasi hingga bangsa tersebut dapat meraih cita-cita yang diinginkannya. Seperti halnya Ideologi Pancasila yang merupakan gagasan besar pendiri bangsa yang dapat menuntun Bangsa Indonesia untuk meraih cita-cita Bangsa Indonesia. Sedangkan demokrasi dapat diartikan sebagai suatu sistem pemerintahan dimana seluruh masyarakatnya memiliki kesempatan, hak dan kewajiban yang sama serta berkontribusi dalam proses pengambilan keputusan. Dari penjelasan tersebut di atas dapat dijelaskan bahwa rakyat memiliki kekuasaan tertinggi dalam hal penentuan keputusan yang berdampak bagi kehidupannya. Pemerintahan yang demokratis akan memberikan kesempatan yang seluas-luasnya kepada seluruh rakyatnya untuk berpartisipasi secara aktif dalam proses perumusan, pengembangan, dan penetapan undang-undang, baik melalui perwakilan ataupun secara langsung.

\section{PEMILIHAN UMUM INDONESIA}

Ciri dari sebuah negara yang merdeka dan berdaulat dengan demokrasi sebagai pegangan dalam kehidupan bernegara adalah adanya pemilihan umum yang diselenggarakan secara berkala dengan waktu dan aturan yang jelas. Demikian pula halnya Indonesia. Negara Indonesia sudah menyepakati bahwa pemilihan umum 
merupakan sarana demokrasi untuk memilih pemimpin negara, DPR, dan DPD sampai ke jenjang Provinsi dan Kabupaten/Kota.

Dalam sejarahnya, pemilihan umum di Indonesia sudah dimulai pada tahun 1955 dimana waktu itu Negara Republik Indonesia baru genap berusia 10 tahun. Pemilihan umum pada waktu itu dilaksanakan dalam dua tahap yaitu pertama pada tanggal 29 September 1955 untuk memilih anggota DPR dan pemilihan kedua dilaksanakan pada tanggal 15 Desember 1955 untuk memilih anggota Badan Konstituante. Namun, kisah sukses Pemilu 1955 tidak dapat dilanjutkan pada lima tahun berikutnya. Pemilu 1955 hanya menjadi goresan tinta emas sejarah. Bukan sampai disitu saja. Presiden Soekarno malah mengeluarkan Dekrit Presiden 5 Juli 1959 yang salah satu isinya adalah membubarkan Konstituante dan pernyataan kembali ke Undang Undang Dasar 1945.

Pemilihan umum berikutnya baru dapat dilaksanakan pada tanggal 5 Juli 1971. Pada waktu itu pemerintahan dibawah kekuasaan Ordee Baru. Pada Pemilu kali ini, terdapat 9 partai politik dan 1 organisasi kemasyarakatan (Ormas). Situasi politik dan ekonomi negara dibawah kekuasaan Orde Baru sangatlah stabil sehingga tidak ada gangguan yang berarti dalam melaksanakan pemilihan umum pada waktu itu. Selama tiga puluh dua tahun berkuasa, Presiden Soeharto dapat menyelenggarakan pemilihan umum setiap lima tahun dengan aman dan lancer. Periode yang dimaksud adalah Pemilu tahun 1977, 1982, 1897, 1992 dab 1977 dengan jumlah peserta sebanyak 3 Peserta yaitu Golongan Karya (Golkar), Partai Demokrasi Indonesia (PDI) dan Partai Persatuan Pembangunan (PPP). Jumlah peserta pemilihan umum yang sedikit ini disebabkan oleh adanya keinginan dari pemerintah dan DPR untuk menyederhanakan jumlah partai politik melalui pemberlakuan Undang Undang nomor 3 tahun 1975 tentang Partai Politik dan Golkar. Dua partai politik tersebut adalah Partai Persatuan Pembangunan (PPP) dan Partai Demokrasi Indonesia (PDI). Dalam setiap kali pemilihan umum, maka Partai Golkar selalu sendapatkan suara diatas $60 \%$ diikuti oleh PPP dan PDI.

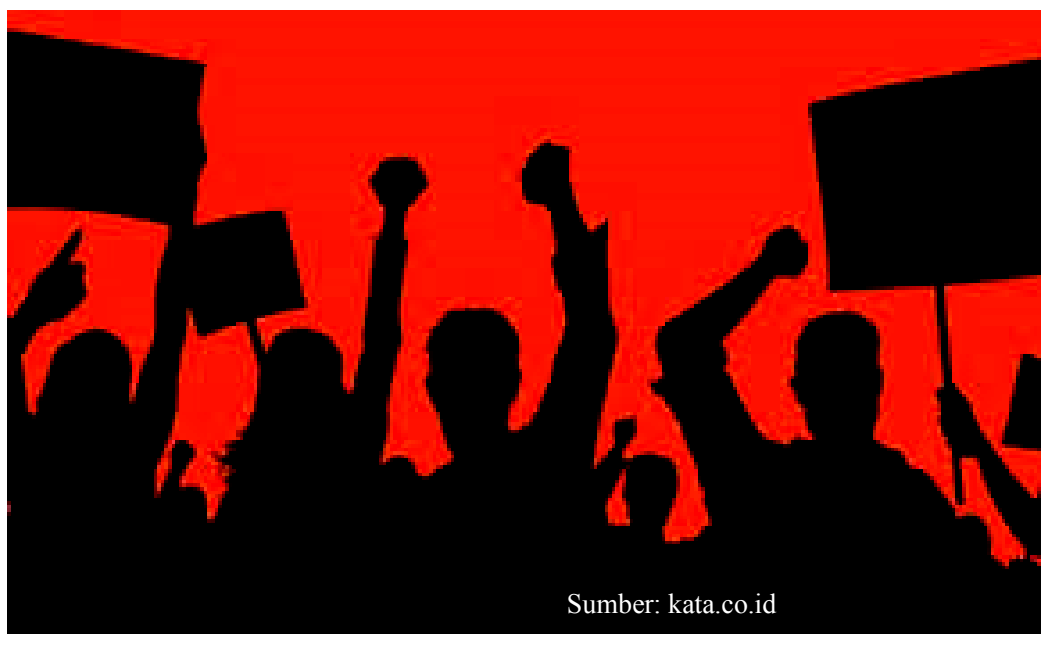

Gerakan reformasi hampir meluluhlantakkan Indonesia. Presiden Soeharto yang sudah berkuasa selama 32 tahun dilengserkan dan digantikan oleh wakilnya yaitu Bacharuddin Jusuf Habibie. Atas desakan publik untuk segera menyelenggarakan pemilihan umum atau pemilihan umum dipercepat maka pada tanggal 7 Juni 1999 dilaksanakanlah pemilihan umum. Pemilihan umum dilaksanakan untuk memilih anggota DPR, DPRD Provinsi dan DPRD Kabupaten/Kota. Berbagai alasan dikemukakan supaya pemilihan umum dapat segera dilaksanakan diantaranya adalah bahwa pemilihan umum dilaksanakan untuk memperoleh pengakuan atau kepercayaan dari publik, termasuk dunia internasional. Mengingat pemerintahan dan lembaga-lembaga yang merupakan produk pemilihan umum 1997 sudah dianggap 
tidak dapat dipercaya. Selanjutnya dilaksanakan Sidang Umum MPR untuk memilih presiden dan wakil presiden yang baru.

Setelah tahun 1999, Indonesia kembali secara rutin menyelenggarakan pemilihan umum setiap lima tahun sekali. Pemilu selanjutnya dilaksanakan pada tahun 2004 yang merupakan pemilu pertama dimana setiap warga negara Indonesia yang memiliki hak pilih, dapat memilih Presiden dan Wakil Presiden secara langsung, selain adanya pemilihan anggota DPR, DPD, DPRD Provinsi dan DPRD Kabupaten/Kota. Pada pemilihan umum 2004 dan 2009 ditetapkannya Parliamentary Threshold sebesar 2,5 persen, Apabila partai politik memperoleh suara kurang dari 2,5 persen maka partai politik tersebut tidak berhak untuk memperoleh kursi di DPR.

Tahun 2014 rakyat Indonesia kembali melaksanakan pemilihan umum. Tanggal 9 April 2014 dilaksanakan pemilihan umum untuk memilih anggota DPR, DPRD Provinsi, DPRD Kabupaten/Kota. Pada tanggal 9 Juli 2014 dilaksanakan pemilihan Presiden dan Wakil Presiden secara langsung.

Melalui Undang Undang Nomor 7 Tahun 2017 tentang Pemilihan Umum (Pemilu) Indonesia memiliki landasan hukum yang kuat untuk menyelenggarakan Pemilihan Umum yang dilakukan serentak diantaranya Pemilihan Presiden dan Wakil Presiden, Pemilihan Anggota DPR, DPRD Provinsi, DPRD Kabupaten/Kota, serta anggota DPD. Pemilihan Umum 2019 ini merupakan torehan sejarah baru bagi pemilihan umum di Indonesia mengingat pada pemilihan umum 2019 inilah untuk pertama kali pemilihan umum DPR, DPRD dan DPD dilaksanakan bersamaan dengan pemilihan Presiden dan Wakil Presiden. Pemilihan umum ini akan dilaksanakan berdasarkan atas azas Langsung, umum, bebas, rahasia, jujur, dan adil. Demikian pula dengan penyelenggara pemilihan umum (KPU) yang dituntut untuk dapat menyelenggarakan pemilihan umum dengan menganut azas mandiri, jujur, adil, berdasarkan atas hukum, tertib, terbuka, proporsional, profesional, akuntabel, efektif, dan efisien. Dengan demikian, pemilihan umum Indonesia tahun 2019 ini merupakan pemilihan umum yang terberat, terumit dan termurah. Termurah dapat diartikan sebagai kegiatan pemilihan umum yang dilaksanakan serentak maka ongkos administrasi dan akomodasi dapat dikurangi.

Bila merekonstruksi kembali Demokrasi Indonesia dari penguasa ke penguasa sejak tahun 1945 sampai saat ini, dapat dilihat bahwa Indonesia telah mengalami paling sedikit empat kali perubahan dan penyesuaian terhadap demokrasi yaitu demokrasi parlementer, demokrasi terpimpin, demokrasi Pancasila (orde baru) dan demokrasi Pancasila (orde reformasi). Penulis lebih tertarik untuk mendalami demokrasi Pancasila pada jaman reformasi ini mengingat banyaknya masalah dan cenderung menjadi bencana demokrasi (democrazy). Pelaksanaan demokrasi Pancasila di jaman reformasi ini diimplementasikan dalam bentuk pemilihan langsung Presiden dan Wakil Presiden, DPT, DPRD Provinsi, DPRD Kabupaten/Kota dan DPD. Penulis berpendapat bahwa sesungguhnya bentuk pemilihan langsung tersebut sangat jauh dari cita-cita demokrasi Pancasila yang sesuai dengan bentuk demokrasi yang dikonsepsikan oleh Bung Karno dan Bung Hatta. Bentuk demokrasi tersebut tersurat dalam salah satu sila dalam sila-sila Pancasila yaitu sila keempat yang berbunyi kerakyatan yang dipimpin oleh hikmat kebijaksanaan dalam permusyawaratan/perwakilan, dengan demikian, kembali pada konsepsi demokrasi ala 
Bung Karno dan Bung Hatta adalah sebuah solusi bijak bagi Bangsa Indonesia untuk masa yangakan datang.

Dikatakan solusi bijak? Mari kita periksa sila keempat Pancasila. Dalam kronologi lahirnya sila keempat tercatat bahwa dalam pidato tanggal 1 Juni 1945, Bung Karno mengakomodir permintaan ketua BPUPKI yang dijabat oleh dr. K.R.T. Radjiman Wediodiningrat tentang philosofische groundslag Indonesia Merdeka. Bung Karno menguraikan tentang "dasar mufakat, dasar perwakilan dan dasar permusyawaratan". Bung Karno meyakinkan anggota BPUPKI bahwa syarat mutlak berdiri dan kuatnya Negara Indonesia adalah permusyawaratan dan perwakilan. Dijelaskan bahwa Indonesia yang didirikan adalah "negara 'semua buat semua', 'satu buat semua', dan 'semua buat satu". Pada sidang berikutnya dirumuskanlah bunyi sila tersebut seperti yang kita kenal sekarang yaitu "Kerakyatan yang dipimpin oleh hikmat kebijaksanaan dalam permusyawaratan/perwakilan".

Selanjutnya sila ini kerap dipahami secara parsial tanpa memahami lagi roh terciptanya sila tersebut. Sering kali kita fokus pada satu aspek seperti "permusyawaratan" saja. Tentu sangat tidak adil terhadap makna keseluruhan dari sila keempat Pancasila. Bagaimana bisa memahami secara mendalam makna sila keempat Pancasila bila kita hanya fokus pada salah satu aspek saja dari sila keempat

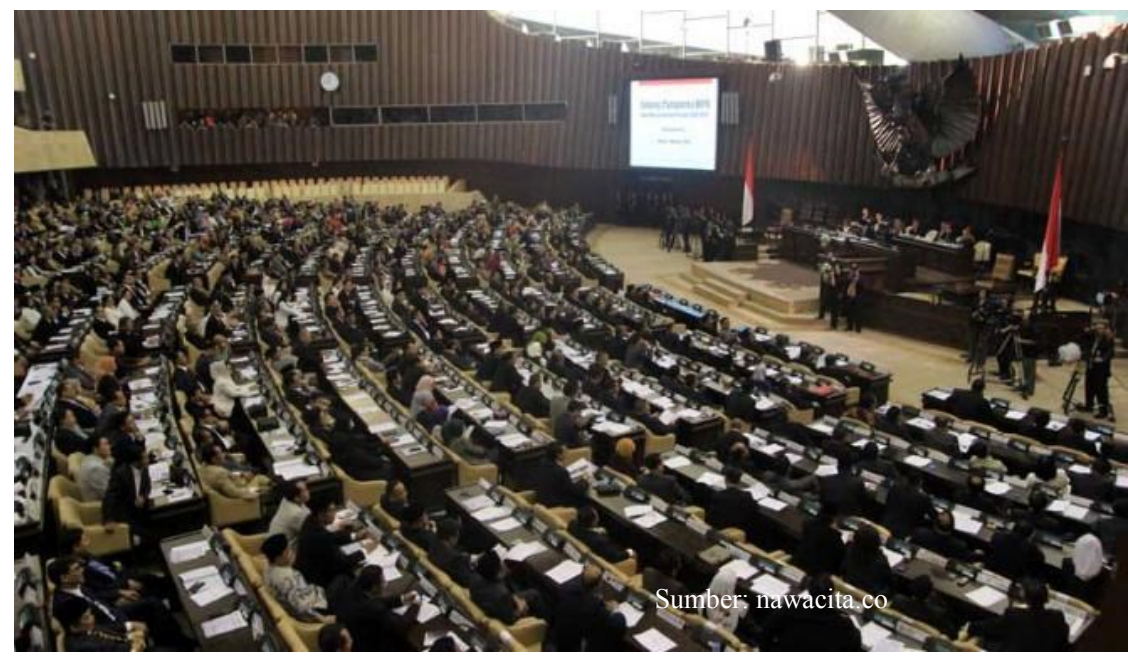
tersebut. Untuk mendapatkan pemahaman yang benar tentang sila keempat Pancasila ada baiknya dikupas satu per satu aspek yang ada pada sila keempat tersebut sehingga kita menemukan betapa dalam dan luasnya makna sila keempat tersebut.

Pertama kita kupas adalah aspek kerakyatan dan aspek demokrasi. Kerakyatan adalah segala sesuatu yang berkenaan dengan rakyat. Namun saat ini makna kerakyatan diartikan sebagai demokrasi. Demokrasi adalah sebuah kata serapan dalam bahasa Indonesia. Dalam penyerapan suatu kata, mustahil kita preteli makna atau konsep aslinya. Konseptual demokrasi adalah murni buah pemikiran masyarakat dari belahan dunia barat. Namun konsep demokrasi menjadi universal dan setiap negara memiliki kisah dan sejarahnya masing-masing. Maka tidak heran kita pernah mencoba untuk menggunakan Demokrasi Parlementer, Demokrasi Terpimpin, dan Demokrasi Pancasila. Mengapa kita mencoba? karena kita mencari sistem yang terbaik dan tercocok untuk Indonesia. Kita mencoba karena kita yakin bahwa demokrasi adalah sebuah alat dan bukan merupakan tujuan. Apakah yang menjadi tujuan demokrasi? Merujuk pada sila-sila Pancasila maka tujuan demokrasi adalah Keadilan sosial bagi seluruh rakyat Indonesia seperti yang tertulis pada sila kelima Pancasila. Apakah Pancasila merupakan suatu sistem perpanjangan sila Pancasila? Tidak. Karena kelima sila-sila Pancasila saling kait mengait antara satu sila dengan sila lainnya sebagai dasar Indonesia Merdeka. Apakah yang menjadi tujuan Kerakyatan? Merujuk pada pembukaan Undang Undang 1045 maka tujuan kerakyatan adalah 
melindungi segenap bangsa dan seluruh tumpah darah Indonesia; memajukan kesejahteraan umum; mencerdaskan kehidupan bangsa dan melaksanakan ketertiban dunia. Jadi kerakyatan adalah segala sesuatu yang mengantarkan rakyat Indonesia untuk mewujudkan tujuan Indonesia Merdeka, dan demokrasi adalah alat untuk mencapai keadilan sosial bagi seluruh rakyat Indonesia.

Kata "dipimpin" dalam bahasa Indonesia merupakan pengejawantahan dari kata "didukung atau didorong". Hal ini nerupakan sifat dari bangsa Indonesia yang memiliki budaya pasif dan ewuh pakewuh. Sebagian karena pribadi atau subyek, yang memandang penerima perbuatan lebih penting dibandingkan dengan pribadi atau subyek. Kepasifan ini lebih terlihat dalam falsafah jawa yaitu "Tut Wuri Handayani" dari belakang mendukung atau mendorong. Jadi Kerakyatan yang didukung atau didorong oleh "hikmat kebijaksanaan", merupakan buah dari permusyawaratan perwakilan yang diyakini dapat mengantarkan rakyat Indonesia kepada tujuan Indonesia merdeka.

Pendiri bangsa juga merumuskan dengan akurat dan memunculkan demokrasi Indonesia dengan kekhasannya. Bukan tokoh atau suara mayoritas yang ditonjolkan tetap "hikmat kebijaksanaan" dijadikan penentu keberhasilan dalam demokrasi Indonesia. Pendiri negara telah menemukan kearifan lokal yang mendalam dalam menentukan kriteria kepemimpinan dan pemempin bangsa. Sehingga pribadi tanpa hikmat kebijaksanaan tidaklah layak untuk memimpin dan memimpin tanpa hikmat kebijaksanaan tidak akan jauh dari kubang kesesatan. Terdapat dua cara untuk memperoleh "hikmat kebijaksanaan". Pertama adalah penguasaan ilmu pengetahuan dan kedua adalah pengalaman langsung dalam menghadapi berbagai macam permasalahan. Kedua cara tersebut telah terangkum dalam rumusan sila keempat dari Pancasila. "Permusyawaratan perwakilan" dapat memberikan kita pengalaman yang langsung dapat menghasilkan "hikmat kebijaksanaan". Jadi "hikmat kebijaksanaan" merupakan daya pimpin yang dapat mewujudkan "kerakyatan".

Bung Karno mengatakan bahwa kita boleh mati-matian berdebat, tetapi hanya di forum ini. Setelah selesai di sini, kita semua bersatu suara, sebab kepentingan bangsa di atas segalanya. Hingga beliau menyarankan agar segala tuntutan dan pertarungan ide berlangsung di forum badan perwakilan. Namun kita juga harus memahami permasalahan sesama. Penjelasan di atas menggambarkan betapa Bung Karno sangat mendalami sebuah demokrasi ala Indonesia.

Dari pemaparan di atas dapat dipetik sebuah pelajaran bahwa demokrasi yang dilaksanakan melalui mekanisme pemilihan umum saat ini dinilai masih jauh dari roh demokrasi yang diinginkan oleh pendiri Bangsa Indonesia. Diperlukan kesadaran oleh pemimpin negeri dan anggota dewan terpilih untuk dapat memahami dan mendalami nilai-nilai dan roh dari demokrasi ala Indonesia. Sehingga demokrasi Indonesia semakin dekat dengan jiwa dan raga rakyat Indonesia.

\section{DAFTAR PUSTAKA}

Ebyhara, Abu Bakar. 2014. Pengantar Ilmu Politik, Penerbit Ruzz Media.

Giddens, Anthony. 2011. The Constitution of Society. Penerbit Pedati. Yogyakarta.

Haris, Syamsuddin. 2018. Pemilu Nasional Serentak 2019. Penerbit Pustaka Pelajar.

Jones, Tod. 2017. Kebudayaan dan Kekuasaan di Indonesia: Kebijakan Budaya Selama Abad Ke-20 hingga Era Reformasi, Penerbit Pustaka Alfabet (Yayasan Pustaka Obor Indonesia). 
Sekretariat Jenderal MPR RI. 2017. Panduan Pemasyarakatan Undang Undang Dasar Negara Republik Indonesia Tahun 1945 Dan Ketetapan Majelis Permusyawaratan Rakyat Republik Indonesia.

Subekti, Valina Singka. 2015. Dinamika Konsolidasi Demokrasi: Dari Ide Pembaruan Sistem Politik Hingga Ke Praktik Pemerintahan Demokratis, Penerbit Pustaka Alvabet (Yayasan Pustaka Obor Indonesia).

Tim Viva Justicia. 2018. Undang-undang Pemilu 2019, Penerbit Genesis Learning.

Weber, Max. 2006. Sosiologi, Penerbit Pustaka Pelajar, Yogyakarta. 
10 | Anak Agung Ngurah Agung Wira Bima Wikrama 